\title{
Synthesis and in vivo evaluation of pyrazoline-thiazolidin-4-one hybrid Les-5581 as a potential non-steroidal anti-inflammatory agent
}

\author{
S. M. Holota ${ }^{1,2,3}$, H. O. Derkach ${ }^{4}$, I. L. Demchuk ${ }^{1}$, R. B. Vynnytska ${ }^{4}$, O. I. Antoniv ${ }^{1}$, \\ L. O. Furdychko , N. Yu. Slyvka ${ }^{2}$, I. O. Nektegayev ${ }^{1}$, R. B. Lesyk ${ }^{1,6}$ \\ ${ }^{1}$ Danylo Halytsky Lviv National Medical University \\ 69, Pekarska Str., Lviv, Ukraine, 79010 \\ 2 Lesya Ukrainka Eastern European National University \\ 13, Volya Av, Lutsk, Ukraine, 43025 \\ ${ }^{3}$ Lviv Medical Institute \\ 76, V. Polischuk Str., Lviv, Ukraine, 79018 \\ ${ }^{4}$ Ivano-Frankivsk National Medical University \\ 2, Halytska Str., Ivano-Frankivsk, Ukraine, 76018 \\ ${ }^{5}$ Bogomolets National Medical University \\ 13, Shevchenko Blvd., Kyiv, Ukraine, 01601 \\ ${ }^{6}$ University of Information Technology and Management in Rzeszow \\ 2, Sucharskiego Str., Rzeszow, Poland, 35-225 \\ golota_serg@yahoo.com,roman.lesyk@gmail.com
}

\begin{abstract}
Aim. Synthesis and in vivo study of acute toxicity, anti-inflammatory (anti-exudative) activity and side effects of pyrazoline-thiazolidin-4-one hybrid Les-5581 under conditions of therapeutic use in experimental animals. Methods. Traditional organic synthesis. The LitchfieldWilcoxon method. Carrageenin- and formaldehyde-induced inflammatory paw edema models of white rats. Clinical laboratory tests: study of general blood parameters and biochemical profile of liver function (ALT, AST, LF and $\gamma$-GGT levels). Evaluation of ulcerogenic action. Results. The target hybrid Les-5581 has been synthesized in a convenient and efficient aminolysis of 5-etoxymethylidenerhodanine by 3,5-bis-(4-chloro-phenyl)-4,5-dihydro-1H-pyrazole. The LD50 value for Les-5581 was determined with intraperitoneal use and it was $510 \mathrm{mg} / \mathrm{kg}$. Les-5581 exhibits significant anti-inflammatory activity at a dose of $50 \mathrm{mg} / \mathrm{kg}$ (intraperitoneal use) in an experiment on carrageenin- and formaldehyde-induced inflammatory models in white rats. The use of Les-5581 does not provoke a negative impact on the blood pattern, the liver enzymes function and has no ulcerogenic effect. Conclusions. The pyrazoline-thiazolidine4-one hybrid Les-5581 is a good molecular platform for development of new potential lowtoxicity anti-inflammatory drugs without ulcerogenic action.

Ke y w o r d s: pyrazoline, thiazolidin-4-one, NSAIDs, molecular hybrid
\end{abstract}

(C) 2019 S. M. Holota et al.; Published by the Institute of Molecular Biology and Genetics, NAS of Ukraine on behalf of Biopolymers and Cell. This is an Open Access article distributed under the terms of the Creative Commons Attribution License (http://creativecommons.org/licenses/by/4.0/), which permits unrestricted reuse, distribution, and reproduction in any medium, provided the original work is properly cited 


\section{Introduction}

Non-steroidal anti-inflammatory drugs (NSAIDs) are among the most frequently prescribed drugs in modern medicine and represent diverse classes of chemical compounds [1]. Usually NSAIDs are taken systematically, for a long time and in the large doses. NSAIDs are characterized by different types of undesirable effects such as gastrointestinal (GI) and cardiovascular risks, hepatoand nephrotoxicity, negative impact on central nervous and blood systems etc [2]. The molecular mechanisms underlying this toxicity have not yet been fully elucidated but it is known that the oxidative stress (OS) and reactive oxygen species (ROS) are key factors which play an important role in the pathogenesis of "NSAIDs-gastropathy" [3], "NSAIDinduced hepatotoxicity" $[4,5]$, etc. Thus, presence antioxidant properties are a desirable and useful characteristic for potential NSAIDs to overcome side effects [6].

New small molecules as modern anti-inflammatory agents with synergic action and minimizing toxicity were developed using molecular hybridization and multiple-ligand drugs techniques $[7,8]$. The combination of anti-oxidative and anti-inflammatory scaffolds in one molecule was shown to be a promising strategy for the search, further optimization and development of new hits/leads/candidates as potent and safe NSAIDs [8,9]. The study of hybridization of potential scaffolds with both antioxidant and anti-inflammatory properties is of particular interest.

The structurally diverse thiazolidin-4-ones and 3,5-disubstituted-2-pyrazolines demonstrate good anti-inflammatory properties. These heterocycles generally realize their anti-iflammatory action through dual COX-2/LOX-5 inhibition, selective COX-2 inhibition or phospholipase A2 activity modulation [10-12]. Moreover, above-mentioned scaffolds possess potentital antioxidant properties. 4-Thiazolidone derivative rosiglitazone, with peroxisome proliferator activated receptor (PPAR- $\gamma$ ) agonism properties, can modulate NADPH-oxidase 4 (NOX4) and decrease the ROS generation induced by hypoxia in the mouse lung as well as human pulmonary artery smooth muscle cells. This effect is probably mediated by NF-kB [13, 14]. Other PPAR- $\gamma$ agonist pioglitazone reduces brain superoxide in stroke-prone spontaneously hypertensive rats by NOX inhibition [15]. A lot of modified 2-pyrazolines demonstrate excellent antioxidant activity compared with the reference standard molecules in in vitro tests such as DPPH assay, NO scavenging, superoxide scavenging, $\mathrm{H}_{2} \mathrm{O}_{2}$-scavenging activity assay $[12,16,17]$ etc.

Our experience in the search for potential pharmacological agents confirms the feasibility of synthesis and study of the properties of hybrid molecules with thiazlodin-4-one and pyrazoline moieties $[18,19]$.

In the present work we describe synthesis and study of pyrazoline-thiazolidin-4-one hybrid Les5581 - its acute toxicity, anti-inflammatory activity on the carragenin- and formaline-induced models, as well as influence on blood pattern, liver function and ulcerogenic impact under the treatment conditions. This work is a part of our research devoted to the search for anti-inflammatory agents and study on the inflammatory processes of different genesis [20-23]. 


\section{Materials and Methods}

Synthesis. All organic chemicals and solvents were procured from Sigma-Aldrich, Merck and used without doing any further purification. For thin-layer chromatography (TLC) analysis, Merck pre-coated plates (silica gel 60 F254) [were] used and spots visualized under UV light. The 5-ethoxymethylene-2-thioxo-thiazolidin-4-one (1) was synthesized using method [24]. 3,5-Bis-(4-chloro-phenyl)-4,5dihydro-1H-pyrazole (2) was synthesized using method [19].

The synthesis of 5-[3,5-bis-(4-chlorophenyl)-4,5-dihydro-pyrazol-1-ylmethylene]2-thioxo-thiazolidin-4-one (3): in a round bottom flask is placed by 0.01 mole of $\mathbf{1}$ and $\mathbf{2}$, add $10 \mathrm{ml}$ of ethanol. The mixture was heated at reflux for 2 hours. After cooling, the precipitate formed is filtered off and recrystallized from DMF-ethanol. Yield: $74 \%$, M.p. $->250{ }^{\circ} \mathrm{C} .{ }^{1} \mathrm{H}$ NMR, $\delta$, ppm: $3.56 \mathrm{dd}, 4.07 \mathrm{dd}, 5.19 \mathrm{~m}(3 \mathrm{H}$, $\mathrm{CH}-\mathrm{CH}_{2}$, pyrazoline), $6.90-7.50 \mathrm{~m}(8 \mathrm{H}$, $\left.2 * \mathrm{C}_{6} \mathrm{H}_{4}\right), 8.00 \mathrm{~s}(1 \mathrm{H},-\mathrm{CH}=), 13.00$ bs $(1 \mathrm{H}, \mathrm{NH})$. ESI-MS: $m / z 435[\mathrm{M}+\mathrm{H}]^{+}(100 \%)$. Calculated, \%: C, 52.54, H, 3.02, N, 9.67. $\mathrm{C}_{19} \mathrm{H}_{13} \mathrm{Cl}_{2} \mathrm{~N}_{3} \mathrm{OS}_{2}$. Found, \%: C, 52.60, H, 3.10, N, 9.80.

Animals. The experiment was performed on white male rats weighing 180-220 $\mathrm{g}$ and white mice of both sexes weighing 20-27 g. All the animals used for this study were kept in standard cages and maintained under controlled laboratory conditions of temperature $\left(22 \pm 3^{\circ} \mathrm{C}\right)$, humidity and 12 hour day-12 hour night and had free access to food (standard pellet diet) and water ad libitum. The animals were treated humanely throughout the study period adhering to the guideline for use and care of animals in declaration of Helsinki (National Research Council, 2011). The ex- periment design and study protocol were approved by the Animal Ethics Committee of the Danylo Halytsky Lviv National Medical University, protocol No. 19, September 17, 2018.

Acute toxicity. The acute toxicity studying was performed to assess the prospects of the synthesized compounds as biologically active substances. The $\mathrm{LD}_{50}$ value was determined by the method of Litchfield and Wilcoxon [25]. Test compounds were dissolved in tween-80 and purified water and administered intraperitoneally. The observation of the animals was performed for 14 days.

Anti-inflammatory (antiexudative) assay. The 54 male albino rats weighing 180-220 g were used for studying antiexudative activity. The selected animals were randomly divided into groups of six in each. The carrageenaninduced hind paw oedema was produced by the method of Winter et al. [26]. Carrageenan solution $(1.0 \%$ in sterile $0.9 \% \mathrm{NaCl})$ was injected subcutaneosly into the subplanar region of the hind paw ( $0.1 \mathrm{~mL}$ to each paw) $1 \mathrm{~h}$ after administration of the test compound. The synthesized compound was intraperitoneally injected in a dose $50 \mathrm{mg} / \mathrm{kg}$ (in saline solution with one drop of Tween-80 ${ }^{\mathrm{TM}}$ ). Diclofenac (tablets "Diclofenac sodium", "Zdorovja narodu", Ukraine) in dose $8 \mathrm{mg} / \mathrm{kg}$; Acetylsalicylic acid (tablets "Acetylsalicylic acid-Darnitsa", "Darnitsa", Ukraine) in dose $100 \mathrm{mg} / \mathrm{kg}$, Ibuprofen (tablets "Ibuprofen-Darnitsa", "Darnitsa", Ukraine) in dose $50 \mathrm{mg} / \mathrm{kg}$; Ketorolac (tablets "Ketanov", "Terapia SA", Romania) in dose $10 \mathrm{mg} / \mathrm{kg}$ were used as reference drug. Control rats received only saline solution with one drop of Tween- $80^{\mathrm{TM}}$. The hind paw volume was measured with an elec- 
tronic onkograph immediately before and $4 \mathrm{~h}$ after carrageenan injection. The formaldehydeinduced paw edema in rats was produced by the injecting of $0.1 \mathrm{ml} 2 \%$ formaldehyde solution into sub-plantar aponeurosis of the left hind limb one hour after the drug administration [27]. Paw volumes were measured $4 \mathrm{~h}$, $24 \mathrm{~h}, 72 \mathrm{~h}$ and $120 \mathrm{~h}$ after formaldehyde injection as described earlier. Diclofenac in dose of $8 \mathrm{mg} / \mathrm{kg}$ was used as a reference drug. The effect of test compounds on a decrease of paw oedema was compared with that in intact control. The antiexudative activity (AEA) was expressed as a decrease of rats paw oedema, calculated using the equation and given in percentage:

$$
\mathrm{AEA}, \%=\frac{\Delta \text { Vcontrol }-\Delta \text { Vexperiment }}{\Delta \text { Vcontrol }} * 100 \%
$$

where $\Delta \mathrm{V}$ control and $\Delta$ Vexperiment - the mean values of the volume difference for control and experimental animals hinds respectively.

Hematological Assays. Sampling blood [from the lateral tail vein of the rats] into vacuum tubes with solution $\mathrm{Na}_{2}$ EDTA was carried out for hematological studies in the appropriate experiment [28]. Level of hemoglobin and blood cells (erythrocytes, plates, leukocytes) was counted by automatic cell counter ABS-Micros 60-OT (Horiba Medical, Montpellier, France) in certified clinical laboratory of Danylo Halytsky Lviv National Medical University. White blood cell morphology was done (after staining by RomanowskyGiemsa) by an experienced clinical laboratory specialist.

Assessment of liver function. The serum collected from the albino rats was used for estimation of biochemical parameters to determine the functional state of the liver. The levels of total alkaline phosphatase (ALP), gamma glutamyltransferase $(\gamma$-GGT), alanine aminotransferase (ALT) and aspartate aminotransferase (AST) were estimated photometrically according to the reported methods using CORMAY ACCENT-200 automatic analyzer (PZ Cormay, Poland).

Ulcerogenic activity estimation. The estimation of ulcerogenic activity was performed according to the recommendations [29]. All animals were sacrificed under deep anesthesia 6 hours after drug treatment, then their stomachs were removed, opened along the great curvature and rinsed with saline solution $0.9 \%$. The gastric mucosa was examined by means of a magnifying glass $(2 \mathrm{X})$ to assess the incidence of redness and spot ulcers. The mucosal damage was evaluated according to the following score: 0 - no visible damage; 1 presence of edema or hemorrhages, 1-3 small ulcers; 2 - several (more than 3) small ulcers or 1 ulcer of considerable size; 3 - ulcer of considerable size (diameter up to $4 \mathrm{~mm}$ ); 4 several large ulcers; 5 - breakthrough ulcer. The gastric mucosal ulceration score was calculated by the difference between the mean score of each treated group and the mean score of control group.

Statistical Analysis. All data were processed using the statistical package Statistica 10.0 (Statsoft/Dell, Tulsa, OK, USA). The descriptive statistics of the data in tables include mean \pm standard error of the mean (SEM) or mean \pm standard deviation. Significance was assessed by using the one-way ANOVA followed by $t$-test. Values were considered statistically significant when $P$ value is less than 0.05 . 


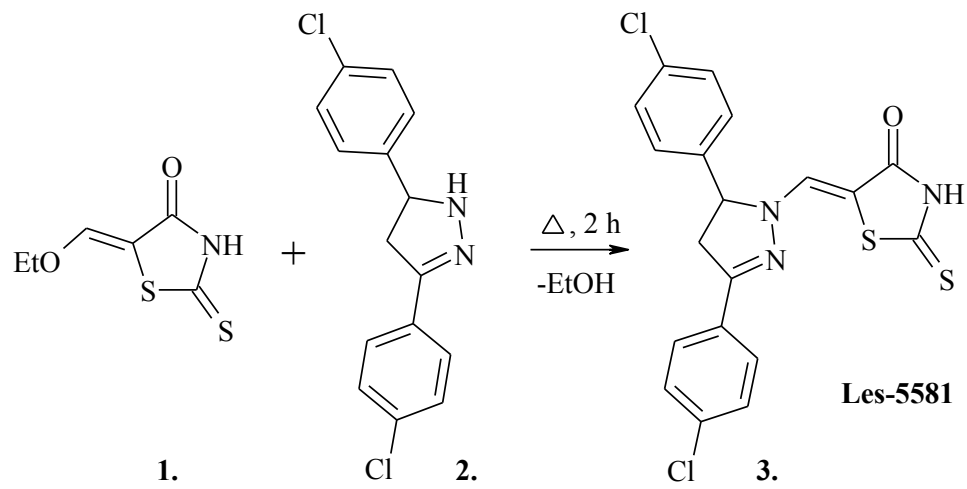

Fig. 1. Scheme of Les-5581 synthesis.

\section{Results and discussion}

The target hybrid Les-5581 has been synthesized in convenient and efficient aminolysis of 5-etoxymethylidenerhodanine (1) by 3,5-disubstituted-2-pyrazoline with satisfactory yield (74\%) and purity according to the scheme (Fig. 1):

The acute toxicity $\left(\mathrm{LD}_{50}\right.$ value $)$ of Les-5581 was studied by intraperitoneally administration in white mice. The approximate doses range from $300 \mathrm{mg} / \mathrm{kg}$ to $800 \mathrm{mg} / \mathrm{kg}$ was established based on series experiments. The $\mathrm{LD}_{50}$ value for Les- 5581 was determined to be $510 \mathrm{mg} / \mathrm{kg}$. During the experiment with dose $510 \mathrm{mg} / \mathrm{kg}$ the animals were clean, active, had satisfactory appetite, responded to sound and light stimuli, the urinary and defecation processes and general behavioral parameters were normal, breathing disorder was noted. The animals deaths during the first day were observed in animal groups that received Les-5581 in a dose of more than $510 \mathrm{mg} / \mathrm{kg}$.

Anti-inflammatory activity of Les-5581 was studied with dose $50 \mathrm{mg} / \mathrm{kg}$, i.e. $0.1 \mathrm{LD}_{50}$ dose. The carrageenan-induced hind paw oedema as the acute process model was used for anti- inflammatory activity estimation at the first stage of experiment. The peak of pathology process was observed 4 hours after the inflammation induction. At this moment, the tested Les-5581 demonstrated a good level of the anti-inflammatory activity ( $40.2 \%$ of inflammation inhibition), which was the same as with Ibuprofen, a little bit higher than with acetylsalicylic acid and ketanov, and only by $13.5 \%$ less than the diclofenac sodium activity (Table 1).

The formaldehyde test was used for the modeling of chronic inflammatory process. Les-5581 at dose of $50 \mathrm{mg} / \mathrm{kg}$ demonstrated good level of activity growing in dynamics over 5 days of experiment (Table 2). Noteworthy, a better anti-inflammatory activity $(45.1 \%)$ was observed on the $5^{\text {th }}$ day $(120 \mathrm{~h})$ compared to diclofenac sodium in these conditions. During the period from $4 \mathrm{~h}$ to $72 \mathrm{~h}$ the antiexudative activity of Les-5581 was a slightly lower than the diclofenac sodium effect.

So, Les-5581 displays promising anti-inflammatory activity in both acute and chronic inflammatory process models.

Hematological profile and impact on blood system of Les-5581 have been estimated in the 
Table 1. In vivo anti-inflammatory activity of Les-5581 on carrageenan-induced paw oedema in rats (intraperitoneally use, $M \pm m, n=6$ in each group)

\begin{tabular}{l|c|c|c}
\hline \multicolumn{1}{c|}{ Groups/Parameters } & Doses & $\begin{array}{c}\text { Rat hind limb volume increase, } \\
\text { 4 hours, \% }\end{array}$ & $\begin{array}{c}\text { Inflammation inhibition, \% } \\
\text { (AEA) }\end{array}$ \\
\hline Carragenan (Pathology model) & $1 \% .0 .1 \mathrm{ml}$ & $131.2 \pm 5.1$ & - \\
\hline Diclofenac sodium & $8.0 \mathrm{mg} / \mathrm{kg}$ & $70.1 \pm 3.2$ & 46.5 \\
\hline Acetylsalicylic acid & $100 \mathrm{mg} / \mathrm{kg}$ & $80.4 \pm 3.5$ & 38.4 \\
\hline Ibuprofen & $50.0 \mathrm{mg} / \mathrm{kg}$ & $78.5 \pm 4.4$ & 40.1 \\
\hline Ketanov & $10.0 \mathrm{mg} / \mathrm{kg}$ & $79.2 \pm 4.2$ & 39.6 \\
\hline Les-5581 & $50.0 \mathrm{mg} / \mathrm{kg}$ & $78.4 \pm 3.8$ & 40.2 \\
\hline
\end{tabular}

Table 2. In vivo anti-inflammatory activity of Les-5581 on formaldehyde-induced paw oedema in rats (intraperitoneally use, $M \pm m, n=6$ in each group)

\begin{tabular}{l|c|c|c|c}
\hline \multicolumn{1}{c|}{ Compounds, doses / Time points } & \multicolumn{3}{|c}{ Growth of oedema (\%) compared to intact animals } \\
\cline { 2 - 5 } & 4 hours & 24 hours & 72 hours & 120 hours \\
\hline Formaldehyde $2 \%, 0.1 \mathrm{ml}($ Pathology model) & $121.6 \pm 8.0$ & $110.3 \pm 7.1$ & $91.1 \pm 6.2$ & $73.1 \pm 6.3$ \\
\hline \multirow{2}{*}{ Les-5581, $50 \mathrm{mg} / \mathrm{kg}$} & $85.0 \pm 7.1$ & $74.6 \pm 6.4$ & $54.3 \pm 4.8$ & $40.1 \pm 3.2$ \\
\hline \multirow{2}{*}{ Diclofenac sodium, $8 \mathrm{mg} / \mathrm{kg}$} & Inhibition of oedema (\%) compared to pathology model \\
\cline { 2 - 5 } & 30.1 & 32.4 & 40.4 & 45.1 \\
\hline
\end{tabular}

end of experiment for both inflammation models in the blood test (Tables 3-5). No influence on blood pattern was observed.
An insignificant increase in the plate level, moderate an increase in the erythrocyte sedimentation rate and strong neutrophilia and

Table 3. Hematological profile of rats with carrageenan-induced paw oedema and treated with Les-5581 and diclofenac sodium (intraperitoneally use, $M \pm m, n=6$ in each group)

\begin{tabular}{l|c|c|c|c}
\hline \multicolumn{1}{c|}{ Groups/Blood parameters } & Intact control & Carragenan, $0,1 \mathrm{ml}, 1,0 \%$ & Les-5581, 50 mg/kg & Diclofenac sodium, $8 \mathrm{mg} / \mathrm{kg}$ \\
\hline ESR, $\mathrm{mm} / \mathrm{h}$ & $0.9 \pm 0.2$ & $2.1 \pm 0.3^{\#}$ & $1.5 \pm 0.1^{*}$ & $1.6 \pm 0.2^{*}$ \\
\hline Hemoglobin, $\mathrm{g} / \mathrm{l}$ & $148 \pm 14$ & $146 \pm 23$ & $148 \pm 19$ & $148 \pm 21$ \\
\hline Red blood cells, $10^{12} / \mathrm{l}$ & $7.9 \pm 0.6$ & $8.1 \pm 0.8$ & $8.2 \pm 0.7$ & $8.0 \pm 0.9$ \\
\hline Plates, $10^{9} / \mathrm{l}$ & $705 \pm 51$ & $823 \pm 71$ & $773 \pm 64$ & $761 \pm 58$ \\
\hline White blood cells, $10^{9} / \mathrm{l}$ & $8.2 \pm 1.2$ & $9.5 \pm 1.1$ & $9.0 \pm 1.2$ & $9.1 \pm 1.5$ \\
\hline Stab leukocytes, $\%$ & $2.1 \pm 0.3$ & $3.2 \pm 0.3^{*}$ & $2.4 \pm 0.3$ & $2.7 \pm 0.3$ \\
\hline Segmental leukocytes, \% & $22.5 \pm 2.4$ & $33.9 \pm 3.9^{*}$ & $28.5 \pm 2.5$ & $30.1 \pm 2.3^{*}$ \\
\hline Lymphocytes, $\%$ & $71.4 \pm 2.4$ & $56.8 \pm 2.3^{*}$ & $63.7 \pm 2.4^{*}$ & $61.8 \pm 2.0^{*}$ \\
\hline Eosinophils, $\%$ & $1.2 \pm 0.3$ & $1.7 \pm 0.3$ & $1.5 \pm 0.3$ & $1.6 \pm 0.3$ \\
\hline Basophils, $\%$ & $0.8 \pm 0.2$ & $0.9 \pm 0.3$ & $0.9 \pm 0.3$ & $0.9 \pm 0.3$ \\
\hline Monocytes, $\%$ & $2.0 \pm 0.4$ & $3.5 \pm 0.4 *$ & $3.0 \pm 0.4$ & $2.9 \pm 0.4$ \\
\hline
\end{tabular}

ESR - Erythrocyte sedimentation rate, ${ }^{*}-\mathrm{p}<0.05$; ${ }^{\#-} \mathrm{p}<0.001$ compared with intact control group 
Table 4. Hematological profile (red blood) of rats with formaldehyde-induced paw oedema and treated with Les-5581 and diclofenac sodium (intraperitoneally use, $M \pm m, n=6$ in each group)

\begin{tabular}{l|c|c|c|c}
\hline $\begin{array}{c}\text { Parameters/ } \\
\text { Time points }\end{array}$ & $\begin{array}{c}\text { ESR, } \\
\mathrm{mm} / \mathrm{h}\end{array}$ & $\begin{array}{c}\text { Hemoglobin, } \\
\mathrm{g} / \mathrm{l}\end{array}$ & $\begin{array}{c}\text { Red blood } \\
\text { cells, } 10^{12} / 1\end{array}$ & $\begin{array}{c}\text { Plates, } \\
10^{9} / \mathrm{l}\end{array}$ \\
\hline \multicolumn{5}{c}{ Intact control } \\
\hline \multicolumn{5}{c}{ Formaldehyde, $2 \%, 0,1 \mathrm{ml}$} \\
\hline $24 \mathrm{~h}$ & $2.7 \pm 0.3^{\#}$ & $152 \pm 14$ & $7.9 \pm 0.6$ & $709 \pm 63$ \\
\hline $72 \mathrm{~h}$ & $1.9 \pm 0.3^{*}$ & $156 \pm 20$ & $8.2 \pm 0.7$ & $756 \pm 55$ \\
\hline $120 \mathrm{~h}$ & $1.5 \pm 0.1$ & $153 \pm 18$ & $8.8 \pm 0.7$ & $732 \pm 59$ \\
\hline \multicolumn{5}{c}{ Les-5581, 50 mg/kg } \\
\hline $24 \mathrm{~h}$ & $1.9 \pm 0.3^{*}$ & $149 \pm 15$ & $8.4 \pm 0.8$ & $733 \pm 47$ \\
\hline $72 \mathrm{~h}$ & $1.5 \pm 0.2^{*}$ & $153 \pm 17$ & $8.6 \pm 0.6$ & $698 \pm 62$ \\
\hline $120 \mathrm{~h}$ & $1.3 \pm 0.3$ & $155 \pm 18$ & $7.9 \pm 0.7$ & $701 \pm 68$ \\
\hline \multicolumn{5}{c}{ Diclofenac sodium, $8 \mathrm{mg} / \mathrm{kg}$} \\
\hline $24 \mathrm{~h}$ & $1.7 \pm 0.3^{*}$ & $150 \pm 19$ & $8.0 \pm 0.5$ & $707 \pm 59$ \\
\hline $72 \mathrm{~h}$ & $1.4 \pm 0.2^{*}$ & $152 \pm 20$ & $8.3 \pm 0.7$ & $686 \pm 70$ \\
\hline $120 \mathrm{~h}$ & $1.2 \pm 0.2$ & $154 \pm 14$ & $8.1 \pm 0.7$ & $735 \pm 81$ \\
\hline
\end{tabular}

ESR — Erythrocyte sedimentation rate, * - p $<0.05$; $\mathrm{p}<0.001$ compared with intact control group lymphocytopenia were observed in experimental animals 4 hours after administration of phlogogenic agents. The application of Les5581 and diclofenac sodium had a positive effect on the blood parameters normalization. The values of the parameters in the groups with treatment by Les-5581 and diclofenac sodium on the 5 th day of the experiment reached the level of intact animals on the formaldehydeinduced paw oedema model. At the same time, in the "pathology model" group, the corresponding indicators on the $5^{\text {th }}$ day reached only the 4-hour level in the treated animals.

A significant increase of liver enzymes levels was observed in the formaldehyde-induced paw oedema conditions for untreated animals (Table 6). If compared with the intact control, in this group the enzymes levels were higher as follows: ALT 1.8-fold, AST 1.9-fold, ALP 1.7-fold, $\gamma$-GGT 1.5-fold.

Table 5. Hematological profile (white blood) of rats with formaldehyde-induced paw oedema and treated with Les-5581 and diclofenac sodium (intraperitoneally use, $M \pm m, n=6$ in each group)

\begin{tabular}{|c|c|c|c|c|c|c|c|}
\hline $\begin{array}{c}\text { Parameters / Time } \\
\text { points }\end{array}$ & $\begin{array}{c}\text { White blood } \\
\text { cells, } 10^{9} / 1 \\
\end{array}$ & $\begin{array}{c}\text { Stab } \\
\text { leukocytes, \% } \\
\end{array}$ & $\begin{array}{c}\text { Segmental } \\
\text { leukocytes, } \% \\
\end{array}$ & $\begin{array}{c}\text { Lymphocytes, } \\
\% \\
\end{array}$ & Eosinophils, \% & Basophils, \% & Monocytes, \% \\
\hline \multicolumn{8}{|c|}{ Intact control } \\
\hline- & $7.3 \pm 1.3$ & $1.4 \pm 0.3$ & $26.2 \pm 1.8$ & $68.5 \pm 1.9$ & $1.2 \pm 0.3$ & $0.9 \pm 0.2$ & $1.8 \pm 0.4$ \\
\hline \multicolumn{8}{|c|}{ Formaldehyde, $2 \%, 0.1 \mathrm{ml}$} \\
\hline $24 \mathrm{~h}$ & $9.6 \pm 1.2 *$ & $2.3 \pm 0.4 *$ & $34.8 \pm 3.3^{*}$ & $56.9 \pm 2.0$ & $1.7 \pm 0.3$ & $0.8 \pm 0.2$ & $3.5 \pm 0.4$ \\
\hline $72 \mathrm{~h}$ & $9.0 \pm 2.4$ & $2.2 \pm 0.3$ & $35.4 \pm 2.9^{*}$ & $56.6 \pm 1.7$ & $1.6 \pm 0.3$ & $0.9 \pm 0.3$ & $3.3 \pm 0.4$ \\
\hline $120 \mathrm{~h}$ & $8.5 \pm 2.0$ & $2.0 \pm 0.3$ & $30.3 \pm 2.2$ & $62.7 \pm 2.2$ & $1.4 \pm 0.3$ & $0.9 \pm 0.3$ & $2.7 \pm 0.4$ \\
\hline \multicolumn{8}{|c|}{ Les-5581, $50 \mathrm{mg} / \mathrm{kg}$} \\
\hline $24 \mathrm{~h}$ & $8.7 \pm 2.1$ & $2.2 \pm 0.4$ & $31.3 \pm 2.7$ & $61.6 \pm 1.8$ & $1.7 \pm 0.4$ & $0.8 \pm 0.2$ & $2.9 \pm 0.3$ \\
\hline $72 \mathrm{~h}$ & $8.3 \pm 2.3$ & $1.7 \pm 0.2$ & $28.7 \pm 2.1$ & $64.9 \pm 2.0$ & $1.4 \pm 0.3$ & $0.8 \pm 0.2$ & $2.5 \pm 0.3$ \\
\hline $120 \mathrm{~h}$ & $8.0 \pm 1.6$ & $1.6 \pm 0.3$ & $27.2 \pm 2.3$ & $66.5 \pm 2.1$ & $1.3 \pm 0.2$ & $0.9 \pm 0.3$ & $2.5 \pm 0.3$ \\
\hline \multicolumn{8}{|c|}{ Diclofenac sodium, $8 \mathrm{mg} / \mathrm{kg}$} \\
\hline $24 \mathrm{~h}$ & $8.9 \pm 1.8$ & $2.1 \pm 0.3$ & $32.8 \pm 3.0$ & $59.5 \pm 2.1$ & $1.6 \pm 0.3$ & $0.9 \pm 0.2$ & $3.1 \pm 0.4$ \\
\hline $72 \mathrm{~h}$ & $8.2 \pm 1.9$ & $1.8 \pm 0.2$ & $27.5 \pm 2.5$ & $65.8 \pm 2.4$ & $1.4 \pm 0.2$ & $0.8 \pm 0.2$ & $2.7 \pm 0.3$ \\
\hline $120 \mathrm{~h}$ & $8.1 \pm 1.9$ & $1.5 \pm 0.4$ & $26.1 \pm 2.4$ & $67.3 \pm 2.2$ & $1.5 \pm 0.2$ & $0.9 \pm 0.3$ & $2.7 \pm 0.3$ \\
\hline
\end{tabular}

${ }^{*} \mathrm{p}<0.05 ;{ }^{*} \mathrm{p}<0.001$ compared with intact control group 
S. M. Holota, H. O. Derkach, I. L. Demchuk et al.

Table 6. The liver enzymes activity in rats with formaldehyde-induced paw oedema and treated with Les-5581 and diclofenac sodium (intraperitoneally use, $M \pm m, n=6$ in each group)

\begin{tabular}{l|c|c|c|c}
\hline $\begin{array}{c}\text { Parameters/Time } \\
\text { points }\end{array}$ & ALT, U/1 & AST, U/1 & ALP, U/1 & $\gamma$-GGT, IU/1 \\
\hline \multicolumn{5}{c}{ Intact control } \\
\hline \multicolumn{5}{c}{ Formaldehyde, $\%$ \%, $0.1 \mathrm{ml}$} \\
\hline $24 \mathrm{~h}$ & $63.2 \pm 7.1$ & $179.1 \pm 21.8$ & $257.5 \pm 15.9$ & $3.4 \pm 0.9$ \\
\hline $72 \mathrm{~h}$ & $119.3 \pm 9.4^{\#}$ & $357.0 \pm 16.5^{\#}$ & $453.8 \pm 39.2^{\#}$ & $5.2 \pm 0.8^{*}$ \\
\hline $120 \mathrm{~h}$ & $95.0 \pm 8.2^{*}$ & $275.5 \pm 19.8^{\#}$ & $378.2 \pm 24.7^{*}$ & $5.3 \pm 1.0^{*}$ \\
\hline \multicolumn{5}{c}{ Les-5581, 50 mg/kg } \\
\hline $24 \mathrm{~h}$ & $79.6 \pm 6.3$ & $223.7 \pm 18.2$ & $305.2 \pm 29.4$ & $4.4 \pm 0.6$ \\
\hline $72 \mathrm{~h}$ & $92.5 \pm 8.5$ & $223.2 \pm 21.0$ & $312.2 \pm 31.6$ & $5.0 \pm 0.7$ \\
\hline $120 \mathrm{~h}$ & $88.2 \pm 7.7$ & $209.8 \pm 18.9$ & $296.9 \pm 28.7$ & $5.4 \pm 1.0 *$ \\
\hline \multicolumn{5}{c}{ Diclofenac sodium, $8 \mathrm{mg} / \mathrm{kg}$} \\
\hline $24 \mathrm{~h}$ & $77.6 \pm 6.8$ & $197.6 \pm 19.0$ & $279.7 \pm 24.5$ & $5.0 \pm 1.1$ \\
\hline $72 \mathrm{~h}$ & $95.9 \pm 6.2^{*}$ & $236.4 \pm 29.4^{*}$ & $293.8 \pm 28.4$ & $5.1 \pm 0.6$ \\
\hline $120 \mathrm{~h}$ & $81.2 \pm 7.0$ & $193.2 \pm 20.3$ & $274.1 \pm 22.8$ & $5.2 \pm 0.9^{*}$ \\
\hline
\end{tabular}

* $-\mathrm{p}<0.05 ;{ }^{\#-} \mathrm{p}<0.001$ compared with intact control group

At the same time, the administration of tested Les-5581 and reference drug does not show any negative impact and results in return from the biochemical changes to a normal level.

Les-5581 was evaluated for the ulcerogenic activity after repeated apllication in dose $50 \mathrm{mg} /$ $\mathrm{kg}$ in rats in the formaldehyde-induced paw oedema test. The results were compared with the intact control group and diclofenac sodium

Table 7. Ulcerogenic pattern of rats with formaldehyde-induced paw oedema and treated with Les-5581 and diclofenac sodium (intraperitoneally use, $M \pm m, n=6$ in each group)

\begin{tabular}{l|c|c}
\hline \multicolumn{1}{c|}{ Parameters/Groups } & $\begin{array}{c}\text { Animals } \\
\text { with } \\
\text { ulcers, n' }\end{array}$ & $\begin{array}{c}\text { Ulcer } \\
\text { degree, } \\
\text { points }\end{array}$ \\
\hline Intact control, $120 \mathrm{~h}$ & 0 & $0 \pm 0.00$ \\
\hline Formaldehyde, $2 \%, 0.1 \mathrm{ml}, 120 \mathrm{~h}$ & 0 & $0 \pm 0.00$ \\
\hline Les-5581, $50 \mathrm{mg} / \mathrm{kg}, 120 \mathrm{~h}$ & 0 & $0 \pm 0.00$ \\
\hline Diclofenac sodium, $8 \mathrm{mg} / \mathrm{kg}, 120 \mathrm{~h}$ & 6 & $1.6 \pm 0.2$ \\
\hline
\end{tabular}

group (Table 7). The second group showed significant ulcerogenic risk with a high ulceration score. The tested compound did not show any ulcerogenic activity.

So, the analysis of results suggests that Les-5581 is [a] good molecular platform for designing new potential anti-inflammatory agents with a low toxicity. The absence of ulcerogenic action and no influence on general blood parameters allow assumption that in the realization of anti-inflammatory effect of Les-5581 the inhibition of COX-2 or LOX-5 plays a key role rather than the COX-1 inhibition. Probably, the presence of half-saturated pyrazoline ring in the Les-5581 structure might have important impact on the compound redox properties. Therefore, the hybrid Les-5581 can reduce the "oxidative stress pathways", which occur under the inflammation process and are responsible for both anti-inflammatory effect realization and ulcerogenic action.

\section{Conclusions}

In the present study we report the anti-inflammatory activity evaluation and toxicity characterization of pyrazoline-thiazolidin-4-one hybrid (Les-5581) in vivo. Les-5581 demonstrated a good level of anti-inflammatory activity in the models of carrageenan- (acute pro- 
cess) and formaldehyde-induced (chronic process) rat paw oedema; it was shown to be moderately toxic by intraperitoneally administration $\left(\mathrm{LD}_{50}=510 \mathrm{mg} / \mathrm{kg}\right)$. The study of side effects indicates that use of Les-5581 does not provoke negative changes in blood test, liver enzymes function and does not manifest the ulcerogenic action. The studied pyrazolinethiazolidin-4-one hybrid is a good candidate for further investigations regarding its potential use in therapy of the inflammatory diseases.

\section{Acknolegments}

This work was partially supported by COST Action NutRedOx-CA161112 "Personalized Nutrition in ageing society: redox control of major aged-related diseases" (for Holota S.).

\section{REFERENCES}

1. Conaghan $P G$. A turbulent decade for NSAIDs: update on current concepts of classification, epidemiology, comparative efficacy, and toxicity. Rheumatol Int. 2012;32(6):1491-502.

2. Meek IL, Van de Laar MA, E Vonkeman H. NonSteroidal Anti-Inflammatory Drugs: An Overview of Cardiovascular Risks. Pharmaceuticals (Basel). 2010;3(7):2146-2162.

3. Nasuti C, Gabbianelli R, Falcioni G, Cantalamessa $F$. Antioxidative and gastroprotective activities of an-ti-inflammatory formulations derived from chestnut honey in rats. Nut Res. 2006; 26(3):130-7.

4. Boelsterli UA. Mechanisms of NSAID-induced hepatotoxicity: focus on nimesulide. Drug Saf. 2002;25(9):633-48.

5. Pandit A, Sachdeva T, Bafna P. Drug-induced hepatotoxicity: a review. J Appl Pharm Sci. 2012; 2(5):233-43.

6. Gaba M, Gaba P, Uppal D, Dhingra N, Bahia MS, Silakari $O$, Mohan $C$. Benzimidazole derivatives: search for GI-friendly anti-inflammatory analgesic agents. Acta Pharm Sin B, 2015; 5(4):337-42.
7. Rao PP, Kabir SN, Mohamed T. Nonsteroidal AntiInflammatory Drugs (NSAIDs): Progress in Small Molecule Drug Development. Pharmaceuticals (Basel). 2010;3(5):1530-1549.

8. Bosquesi PL, Melo TR, Vizioli EO, Santos JL, Chung MC. Anti-Inflammatory Drug Design Using a Molecular Hybridization Approach. Pharmaceuticals (Basel). 2011;4(11):1450-1474.

9. Sawraj S, Bhardawaj TR, Sharma PD. Design, synthesis, and evaluation of novel indomethacinantioxidant codrugs as gastrosparing NSAIDs. Med Chem Res, 2012; 21(6):834-43.

10. Kaminskyy D, Kryshchyshyn A, Lesyk R. 5-Ene4-thiazolidinones - An efficient tool in medicinal chemistry. Eur J Med Chem. 2017; 140:542-594.

11. Geronikaki AA, Lagunin AA, Hadjipavlou-Litina DI, Eleftheriou PT, Filimonov DA, Poroikov VV, Alam I, Saxena $A K$. Computer-aided discovery of anti-inflammatory thiazolidinones with dual cyclooxygenase/lipoxygenase inhibition. $J$ Med Chem. 2008;51(6):1601-9.

12. Marella A, Ali MR, Alam MT, Saha R, Tanwar O, Akhter M, Shaquiquzzaman M, Alam MM. Pyrazolines: a biological review. Mini Rev Med Chem. 2013;13(6):921-31.

13. Saso L, Firuzi O. Pharmacological applications of antioxidants: lights and shadows. Curr Drug Targets. 2014;15(13):1177-99.

14. Golbidi S, Laher I. Antioxidant therapy in human endocrine disorders. Med Sci Monit. 2010;16(1): RA9-24. Review.

15. Lu X, Murphy TC, Nanes MS, Hart CM. PPAR \{gamma\} regulates hypoxia-induced Nox4 expression in human pulmonary artery smooth muscle cells through NF-\{kappa\}B. Am J Physiol Lung Cell Mol Physiol. 2010;299(4):L559-66.

16. Kumar A, Varadaraj BG, Singla RK. Synthesis and evaluation of antioxidant activity of novel 3, 5-disubstituted-2-pyrazolines. Bull Fac Pharm Cairo Univ, 2013; 51(2):167-73.

17. Jagadish PC, Soni N, Verma A. Design, synthesis, and in vitro antioxidant activity of 1, 3, 5-trisubstituted-2-pyrazolines derivatives. J Chem, 2013: ID 765768 . 
18. Havrylyuk D, Roman $O$, Lesyk $R$. Synthetic approaches, structure activity relationship and biological applications for pharmacologically attractive pyrazole/pyrazoline-thiazolidine-based hybrids. Eur J Med Chem. 2016;113:145-66.

19. Havrylyuk D, Zimenkovsky B, Karpenko O, Grellier P, Lesyk $R$. Synthesis of pyrazoline-thiazolidinone hybrids with trypanocidal activity. Eur J Med Chem. 2014;85:245-54.

20. Golota S, Sydorenko I, Surma R, Karpenko O, Gzella A, Lesyk R. Facile one-pot synthesis of 5-aryl/heterylidene-2-(2-hydroxyethyl-and 3-hydroxypropylamino)-thiazol-4-ones via catalytic aminolysis. Synth Comm, 2017; 47(11): 1071-6.

21. Cherkas A, Golota S. An intermittent exhaustion of the pool of glycogen in the human organism as a simple universal health promoting mechanism. Med Hypotheses. 2014;82(3):387-9.

22. Cherkas A, Eckl P, Gueraud F, Abrahamovych O, Serhiyenko V, Yatskevych O, Pliatsko M, Golota S. Helicobacter pylori in sedentary men is linked to higher heart rate, sympathetic activity, and insulin resistance but not inflammation or oxidative stress. Croat Med J. 2016;57(2):141-9.

23. Holota S, Shylych Ya, Derkach H, Karpenko O, Gzella A, Lesyk R. Synthesis of 4-(2H-[1,2,4]-Triazol-5-ylsulfanyl)-1,2-dihydropyrazol-3-one via Ring-Switching Hydrazinolysis of 5-Ethoxymethylidenethiazolo[3,2-b][1,2,4]triazol-6-one. Molbank, 2018; 2018(4):M1022.

24. Lo CP, Croxall WJ. 5-Alkoxymethylenerhodanines and their Reactions with Rhodanines. JACS, 1954; 76(16):4166-9.

25. Litchfield JJ, Wilcoxon F. A simplified method of evaluating dose-effect experiments. J Pharm Exp Therap, 1949; 96(2):99-113.

26. Winter CA, Risley EA, Nuss GW. Carrageenin-induced edema in hind paw of the rat as an assay for antiiflamma-tory drugs. Proc Soc Exp Biol Med, 1962; 111:544-7.

27. Trinus FP, Mochort NA, Klebanov BM. Nesteroidnyje protivospalitelnyje sredstva (Non-steroidal an-ti-inflammatory drugs), Kyiv: Zdorov'ya, 1975; $238 \mathrm{p}$
28. Lee G, Goosens $K A$. Sampling blood from the lateral tail vein of the rat. J Vis Exp. 2015; (99):e52766.

29. Stefanov $O V$. Doklinichni doslidzhennya likarskyh zasobiv: Metodychni rekomendatsii (Preclinical studies of drugs. Guidelines), Kyiv. 2001; 528 p.

\section{Синтез та оцінка in vivo піразолін-тіазолідин-4- онового гібриду Les-5581 як потенційного нестероїдного протизапального агента}

С. М. Голота, Г. О. Деркач, І. Л. Демчук, Р. Б. Винницька, О. І. Антонів, Л.О. Фурдичко, Н. Ю. Сливка, І. О. Нєктєгаєв, Р. Б. Лесик

Мета. Синтез, in vivo дослідження гострої токсичності, протизапальної (антиексудативної) активності та оцінка побічних ефектів в умовах терапевтичного застосування на експериментальних тваринах піразолін-тіазолідин-4-онового гібриду Les-5581. Методи. Традиційний органічний синтез. Метод Літчфілда і Уілкоксона. Моделі каррагенін- та формальдегід-індукованого запального набряку лапи білих щурів. Клінічні лабораторні тести: дослідження загальних параметрів крові та біохімічного профілю функції печінки (рівні АЛТ, АСТ, ЛФ та $\gamma$-ГГТ). Оцінка ульцерогенної дії. Результати. Здійснено синтез цільового гібриду Les-5581 за допомогою зручного та ефективного амінолізу 5-етоксиметиліденроданіну при дії 3,5-біс-(4-хлорфеніл)-4,5-дигідро$1 H$-піразолу. Визначено показник $\mathrm{LD}_{50}$ для Les-5581 при внутрішньоочеревинному введенні, який становить 510 мг/кг. Встанолено, що Les-5581 проявляє значну протизапальну активність в дозі 50 мг/кг (внутрішньоочеревинне введення) на каррагенін- та формальдегід-індукованих моделях запального процесу у білих щурів. В той же час застосування Les-5581 не спричиняє ульцерогенної дії та негативного впливу на загальні показники крові, функцію ензимів печінки. Висновки. Піразолін-тіазолідин-4-оновий гібрид Les-5581 є хорошою молекулярною платформою для розробки нових потенційних протизапальних засобів з низькою токсичністю та відсутністю ульцерогенної дії.

Кл ю ч о в і с л о в а: піразолін, тіазолідин-4-он, НПЗ3, молекулярний гібрид 
Синтез и оценка in vivo пиразолин-тиазолидин4-онового гибрида Les-5581 как потенциального нестероидного противовоспалительное агента

С. Н. Голота, Г. О. Деркач, И. Л. Демчук, Р. Б. Винницкая, О. И. Антонив, Л.О. Фурдычко, Н. Ю. Слывка, И. А. Нектегаев, Р. Б. Лесык

Цель. Синтез, in vivo исследования острой токсичности, противовоспалительной (антиэкссудативной) активности и оценка побочных эффектов в условиях терапевтического применения на експериментальних животных пиразолин-тиазолидин-4-онового гибрида Les-5581.

Методы. Традиционный органический синтез. Метод Литчфилда и Уилкоксона. Модели каррагенин- и формальдегид-индуцированного воспалительного отека лапы белых крыс. Клинические лабораторные тесты: исследование общих параметров крови и биохимического профиля функции печени (уровни АЛТ, АСТ, ЩФ и $\gamma$-ГГТ). Оценка ульцерогенного действия. Результаты. Осуществлён синтез целевого гибрида Les-5581 с помощью удобного и эффективного аминолиза 5-етокси- метилиденроданина при действии 3,5-бис-(4-хлорфенил)-4,5-дигидро-1Н-пиразола. Определено значение LD50 для Les-5581 при внутрибрюшинном введении, которое составляет 510 мг/кг. Установлено, что Les-5581 проявляет значительную противовоспалительную активность в дозе 50 мг/кг (внутрибрюшинное введение) на каррагенин- и формальдегид-индуцированных моделях воспалительного процесса у белых крыс. В то же время применение Les-5581 не вызывает негативного влияния на общие показатели крови, функцию энзимов печени и не оказывает ульцерогенного действия. Выводы. Пиразолин-тиазолидин-4-оновый гибрид Les5581 является хорошей молекулярной платформой для разработки новых потенциальных противовоспалительных средств с низкой токсичностью и отсутствием ульцерогенного действия.

Кл юч е в ы е с л о в а: пиразолин, тиазолидин-4-он, НПВП, молекулярный гибрид

Received 08.06.2019 